\title{
EARLY VOTING AND SATISFACTION WITH VOTE CHOICE
}

\begin{abstract}
Voting early allows people to vote at the time that is most convenient to them. There is the risk, however, that those who vote early miss out important information about the candidates or parties because that information became available late in the campaign, after they voted. In this study, we examine whether early voting reduces satisfaction with vote choice. Using unique individual-level data from 16 surveys in national and regional elections in 4 countries and more than 15,000 voters, we show that early voters tend to be slightly less satisfied with their vote choice than those who vote on Election Day. However, this negative effect of early voting on satisfaction with vote choice is not universal and is quite modest.
\end{abstract}

Key Words: Early voting, campaign, elections, vote by mail. 


\section{Introduction}

The increasing adoption of early or convenience voting -understood as any system where voters can cast their ballot before the official Election Day (Gronke et al., 2007: 639), mainly absentee voting, mail-in voting, and in-person early voting- around the world in the last decades has fostered a thriving research on the electoral consequences of how and when votes are cast and an intense political debate in the mass media about its pros and cons. For instance, some weeks before the 2014 midterm elections in the US, the American magazine National Review warned that 'we will become a nation in which less than half of us vote on Election Day and the rest of us vote during Election Month. I doubt we'll find the results to be an improvement; after all, we'd see much more of all the things people say they don't like about politics: longer campaigns, more spending, more micro-targeted and poll-driven messages directed to niche voters, and a less-informed electorate.' ("The Trouble with Early Voting", National Review, October 19, 2014). ${ }^{2}$

Existing research has focused on the partisan consequences and turnout implications of early voting (see Gronke et al., 2008; Fullner, 2015: Stein and Vonnahme, 2010 or Vivekinan et al., 2016 for a presentation of the state of the art). In this paper we examine a different and unexplored question, whether early voting affects satisfaction with one's vote choice. As early voters may lose out campaign information, our expectation is that they should be less satisfied with their vote choice than those who vote on the Election Day. Satisfaction with vote choice is captured with retrospective evaluation of vote choice in postelection surveys. The data come from 16 surveys in national and regional elections in 4 countries and more than 15,000 voters.

\section{Arguments}

The main argument in favor of early voting is that it makes it easier for people to vote as they can cast their ballot at the time that is most convenient to them. Because it is easier to vote, early voting fosters a higher turnout. However, the empirical evidence about the impact of early voting on turnout is ambiguous. Gronke et al. (2008) show that early voting has a small positive impact on turnout, while Stein (1998) and Stein

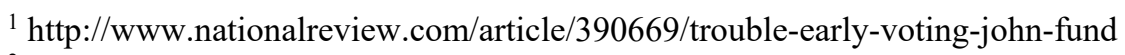

${ }^{2}$ See also http://theweek.com/articles/610117/down-early-voting in the British news magazine The Week.
} 
and Garcia-Monet (1997) report no significant effect, and Burden et al. (2013) suggests that it may have a negative impact.

Perhaps the main argument against early voting is that those who vote before Election Day are deprived of the information that comes out in the late stage of the campaign, after they had voted. In some sense, the vote of early voters is based on less information that that of those who vote on Election Day. There is thus the risk early voters could have voted for a different party if they had voted on Election Day. This is the concern that we are addressing in this paper.

This is a legitimate concern. A vast literature has shown that campaigns matter, and that many voters change their vote intentions as they learn more about the parties, the candidates, their positions and their characters (Brady and Johnston 2006; Jennings and Wlezien 2016). More specifically, typically between $10 \%$ and $15 \%$ of voters change their mind about which party to support in the last 10 days of the campaign (Blais 2004). So are not early voters deprived of some crucial information because they make a decision before the campaign is over?

As far as we can tell, only one prior study has examined this question. Meredith and Malhotra (2011) examine votes cast for presidential candidates in California's primary election in 2008, and show that a significant number of voters missed important information by voting (early) by mail: a significant proportion of voters did not incorporate information about candidates' withdrawals - which occurred six days prior to Election Day- on voting-by-mail ballots. Using matching and regression discontinuity regression design in the 2008 California presidential primary, Meredith and Malhotra (2011) compare the vote shares of candidates in precincts containing more and less than 250 registered voters. In the former, the California Election Code permits county elections officials to require all voters to use voting-by-mail. According to their estimates, vote my mail made a clear difference. Specifically, Meredith and Malhotra (2011) estimate that between 35 and 50 percent of John Edwards voters and 20-30 percent of Rudy Giuliani and Fred Thompson voters would have voted differently if they had not voted my mail (Meredith and Malhotra, 2011: 241). 
Although very valuable, Meredith and Malhotra's analysis is limited to one specific case, and it is not clear whether their findings from primaries are generalizable to national or regional elections. Our examination of early voting is also focused on whether the elimination of late campaign information for the early voting electorate makes a difference. However, instead of comparing different units (precincts), unique survey data from the Making Electoral Democracy Work project (Blais, 2010) allows us to examine whether voters are satisfied with their vote choice once their information about the election is updated, immediately after the election. As rolling cross-section data across the campaign are not available, our analysis does not examine whether early voters forego information, but rather looks at the consequences of losing out information in terms of satisfaction with vote choice, after the election.

We use two key questions from post-election surveys asking people whether they voted early or on Election Day $^{3}$ and whether they are satisfied or not with their vote choice. ${ }^{4}$ All else equal, if late campaign information makes a difference for vote choice, we should observe that early voters are less happy with their vote choice than those who vote on Election Day. However, if there are no differences between the two groups of voters in terms of their satisfaction with vote choice, satisfaction with vote choice for early and Election Day voters would be similar.

As individuals are asked after the election whether they think their decision to vote for the party they voted was good or bad, the unit homogeneity assumption is met: we are comparing the judgments of early and Election Day voters ex post, at the same time, about a decision that the two groups made at different times. It is obvious, however, that early voters are not a random sample of the electorate; this means that we have to control for political and socio-demographic variables affecting both the propensity to vote early and satisfaction with vote choice.

\footnotetext{
${ }^{3}$ The specific question is the following: In Germany and Spain, "Did you vote in person on Election Day or by mail? In person on Election Day, by mail, Don't know". In Canada the question is slightly different: "Did you vote on Election Day or at an advance poll or by special measures?" In Switzerland: "Did you vote in person on Election Day, or did you vote early in person or by mail?"

${ }^{4}$ The specific question is the following: "Given the outcome of the election, do you think that your decision to vote for [party you voted for] was a very bad decision, a fairly bad decision, a fairly good decision or a very good decision?"
} 


\section{Data and Methods}

Our analysis of whether satisfaction with vote choice differs between early voters and Election Day voters is conducted using individual-level data from national and regional elections in Canada, Germany, Spain and Switzerland. The four countries have different early voting procedures. Both in Canada and Switzerland postal voting and in-person advance voting are available for voters, but they are used differently used in the two countries. In Canada, postal balloting is available in special circumstances (such as for overseas voters) and most Canadians who vote early take advantage of inperson advance polls set up at a number of polling stations, usually the weekend before the election (Holly, 2016). More specifically, four days -Friday, Saturday, Sunday and Monday, the 10th, 9th, 8th and 7th days before Election Day- are designated for advance voting (www.electionscanada.ca). In our surveys (see Table 2), the share of early voters is about the 33 percent in Canada. In Switzerland, about 85 per cent of individuals vote by postal ballot. Ballot papers are delivered by cantonal authorities to all voters at least ten days before Election Day and to out-of-country voters at least one week before the general mailing of ballots. Because of the prevalence of postal voting, the number of polling stations and the length of polling hours have been greatly reduced. The federal law requires polling stations to be open for an unspecified length of time during a minimum of two of the four days prior to the Election Day for advance voting (http://www.osce.org/odihr/87417?download=true).

In Germany and Spain only postal voting is available for voters. To take advantage of postal voting in Germany, voters must apply for a mail-in ballot, and then mail the ballot or hand-deliver it to a municipal office. The polling card and the postal ballot documents are sent to voters about six weeks before the election at the earliest. The postal ballot letter must be received by the competent authority not later than 6 p.m. on Election Day. The postal ballot letter should be posted in Germany not later than on the third working day before the election to make sure it is received in time (https://www.bundeswahlleiter.de/en). ${ }^{5}$ Finally, in Spain, once the elections have been called, voters can apply for a postal vote until 10 days before Election Day. Voters have to go in person to any post office and fill in the application form for the certificate of registration in the electoral roll. The Electoral Board will send the official ballots and

\footnotetext{
${ }^{5}$ For more details about early voting procedures in Canada, Germany and Switzerland, see Holly (2016).
} 
envelopes to the voter between 20 and 7 days before Election Day, and the voter has to cast her vote and send it by special (free) postal mail to the polling station at least three days before Election Day (http://www.juntaelectoralcentral.es/cs/jec/loreg).

The cost of postal voting in terms of time and effort for voters is very different in Germany, Spain and Switzerland. Postal voting is easiest in Switzerland and most difficult in Spain, Germany being in the middle. This explains the huge difference in the shares of early voters in Switzerland (91 percent) and Spain (about 4 percent) according to our surveys (see Table 2). In Germany, according to our surveys, the share of early voters is 41 percent.

As the surveys do not provide information about the exact day when early voters voted, it is not possible to formulate any hypothesis about the effect of the number of days available to vote before the Election Day on satisfaction with voting decision in our sample of countries.

The individual-level data come from the surveys conducted by the Making Electoral Democracy Work (MEDW) project (Blais, 2010). To the best of our knowledge, these are the only post-election surveys that include two questions asking respondents to indicate whether (i) they voted in person on the Election Day or in advance and (ii) whether 'you think that the decision to vote for the party you voted for was a very good decision, a fairly good decision, a fairly bad decision, or a very bad decision.'

We have in total 16 surveys that were conducted in Canada, Germany, Spain and Switzerland between 2011 and 2015. In each of these countries we selected two regions (three in the 2015 federal election in Canada) and in each region we covered one national and one regional election. Table A1 in the Appendix lists all the surveys and indicates the number of respondents in each survey and in total, which includes only those who provided information about all the variables considered in our analyses. All the surveys contain a post-election wave, conducted in the week following the election. Except for Bavaria and the 2015 Canadian election (for which we have much larger samples), the sample consists of about 750 respondents in the post-election wave. All 
surveys are internet surveys with samples that are representative of the electorate with respect to age, gender, education, and sub-regions.

When running the regression models, the data from national and regional elections in each country have been pooled to increase the sample size and have more robust estimates. As the variables have been measured exactly in the same way in the four countries and the methodological design of all surveys is similar, the ex-post harmonization of data is not an issue and the data are perfectly comparable (Granda et al., 2010). At the conclusion of the survey data collection and cleaning, the data were weighted by age, gender and education to reflect the actual proportions found in the population. This ensures the findings from the research can be extrapolated to the entire population with accuracy (see http://electoraldemocracy.com/ for more details). ${ }^{6}$

The dependent variable is ordinal. It takes the value 1 if the respondent thinks that her vote choice was 'a very bad decision', 2 if the respondent thinks that it was a 'fairly bad decision', 3 when the response is 'a fairly good decision', and 4 if the respondent thinks that her vote choice was a "very good decision'. ${ }^{7}$ The distribution of the dependent variable in the four countries is displayed in Table 1.

Table 1: Satisfaction with vote choice $(\%)^{\mathrm{a}}$

\begin{tabular}{l|c|c|c|c}
\hline Vote decision & Canada & Germany & Spain & Switzerland \\
\hline Very bad & 0.5 & 0.9 & 0.9 & 0,3 \\
\hline Fairly bad & 2.6 & 3.9 & 2.9 & 1.7 \\
\hline Fairly good & 36.1 & 44.6 & 45.7 & 47.9 \\
\hline Very good & 60.8 & 50.6 & 50.5 & 50.1 \\
\hline Total & 100 & 100 & 100 & 100 \\
& $(4,540)$ & $(8,216)$ & $(1,997)$ & $(1,755)$ \\
\hline
\end{tabular}

${ }^{\mathrm{a}}$ (Post)Weighted by age, gender and education.

Source: MEDW surveys.

Given that the dependent variable is ordinal, ordered logistic regressions have been run. Finally, although the structure of the data is clearly hierarchical (by country, region, and year), we have decided not to run a multilevel model. According to the oft-

\footnotetext{
${ }^{6}$ When running the models without this weight, the results are very similar. The results are very similar when weighting by region within countries. The results are available upon request.

${ }^{7}$ In Germany and Switzerland the analysis considers the list vote, not the candidate vote, in order to have comparable results across countries. The question was not asked in the Madrid regional election.
} 
cited rule of thumb, doing a multilevel analysis requires at least 20 groups and 30 observations per group (Heck and Thomas, 2000). Alternative recommendations are 30 groups and 30 observations per group (Hox, 2002) or 50 groups and 30 observations per group (Mass and Hox, 2004). In our case, only four countries and eight regions are available. All standard errors are clustered by survey (i.e., by region, election and year) to account for non-independence in the data structure. ${ }^{8}$

The key independent variable, Early voter, is a dummy variable coded 1 if the respondent voted (in person or by mail) before Election Day and 0 if she voted in person on Election Day. We have included some conventional controls (see Blais et al., 2017): partisanship (0 if the respondent does not feel close to any particular political party, 1 if she feels close to any particular party), education (from 1 to $7 / 11$, with 1 corresponding to the lowest level of educational attainment and 7/11 to the highest level), gender ( 0 male, 1 female), age (in years), whether the respondent voted or not for the party which won the election, political interest (from 0 , no interest at all, to 10 , a great deal of interest), whether the election is national (0) or regional (1) and region dummies.

\section{Results}

In Table 2 we compare how satisfied Election Day voters and early voters are with their vote choice in the four countries using the 1 ('a very bad decision') -4 ('a very good decision') scale. In three out of the four countries (Germany, Spain and Switzerland), Election Day voters are slightly more satisfied with their vote choice than early voters, while in Canada there are no differences. However, the differences between the two groups of voters are not statistically significant in any of the four countries.

\footnotetext{
${ }^{8}$ In Bavaria, the data come from a panel survey covering the federal and state elections instead of two independent surveys. For this reason there are only three clusters in Germany.
} 
Table 2: Satisfaction with vote choice and timing of decision ${ }^{\mathrm{a}}$

\begin{tabular}{l|c|c|c}
\hline & & \multicolumn{2}{|c}{ Satisfaction with vote choice (1-4) } \\
\hline Country & \% Early voters & Election Day voters & Early voters \\
\hline Canada & 33.2 & 3.6 & 3.6 \\
\hline Germany & 41.3 & 3.5 & 3.4 \\
\hline Spain & 4.2 & 3.5 & 3.4 \\
\hline Switzerland & 91.1 & 3.6 & 3.5 \\
\hline Average & 42.5 & 3.6 & 3.5 \\
\hline
\end{tabular}

${ }^{\mathrm{a}}$ (Post)Weighted by age, gender and education.

As early voters are not a random sample of the electorate, we examine in Table 3 the relationship between the timing of vote choice and satisfaction with vote choice through an ordered logistic regression in which the controls are included. In Germany, Spain and Switzerland, the coefficient on Early voter is negative, that is, those who vote before Election Day are less satisfied with their vote choice than those who vote on Election Day, and statistically significant at the 0.05 (in Germany) and the 0.01 (in Spain and Switzerland) levels. In Canada, however, being an early voter or an Election Day voter does not make a significant difference for satisfaction with vote choice.

Most of the controls behave as expected. Partisanship and political interest have the most robust effects across countries. Both have a positive and statistically significant impact on satisfaction with vote choice in the four countries. Similarly, respondents in the four countries who voted for the winner are happier with their vote choice than respondents who did not, but the effect is only statistically significant in Canada and Germany. The remaining controls have erratic effects across countries. 
Table 3: Ordered logistic regression of satisfaction with vote choice

\begin{tabular}{|c|c|c|c|c|}
\hline & Canada & Germany & Spain & Switzerland \\
\hline Early voter & $\begin{array}{c}0.046 \\
(0.094)\end{array}$ & $\begin{array}{c}-0.041^{* *} \\
(0.020)\end{array}$ & $\begin{array}{c}-0.377 * * * \\
(0.117)\end{array}$ & $\begin{array}{c}-0.419 * * * \\
(0.150)\end{array}$ \\
\hline Partisan & $\begin{array}{c}0.822 * * * \\
(0.114)\end{array}$ & $\begin{array}{c}0.712^{* * * *} \\
(0.087)\end{array}$ & $\begin{array}{c}0.703 * * * \\
(0.016)\end{array}$ & $\begin{array}{c}0.570 * * \\
(0.244)\end{array}$ \\
\hline Education & $\begin{array}{c}-0.020 \\
(0.015)\end{array}$ & $\begin{array}{c}-0.027^{* *} \\
(0.014) \\
\end{array}$ & $\begin{array}{c}0.033^{* * *} * \\
(0.004)\end{array}$ & $\begin{array}{c}-0.014 \\
(0.019)\end{array}$ \\
\hline Female & $\begin{array}{c}0.019 \\
(0.052) \\
\end{array}$ & $\begin{array}{c}-0.068 \\
(0.041)\end{array}$ & $\begin{array}{c}-0.327^{* *} \\
(0.142)\end{array}$ & $\begin{array}{c}-0.128 * * \\
(0.062)\end{array}$ \\
\hline Age & $\begin{array}{c}0.013 * * * \\
(0.004)\end{array}$ & $\begin{array}{c}0.001 \\
(0.004)\end{array}$ & $\begin{array}{c}0.010^{* *} \\
(0.004)\end{array}$ & $\begin{array}{c}-0.008 * * * \\
(0.003)\end{array}$ \\
\hline Voted for National Winner & $\begin{array}{c}0.522 * * * \\
(0.181)\end{array}$ & $\begin{array}{c}0.749 * * * \\
(0.064)\end{array}$ & $\begin{array}{c}0.448 \\
(0.399)\end{array}$ & $\begin{array}{c}0.064 \\
(0.132)\end{array}$ \\
\hline Political Interest & $\begin{array}{c}0.077 * * * \\
(0.025) \\
\end{array}$ & $\begin{array}{c}0.111 * * * \\
(0.013)\end{array}$ & $\begin{array}{c}0.023 * * \\
(0.012)\end{array}$ & $\begin{array}{c}0.197 * * * \\
(0.047) \\
\end{array}$ \\
\hline Regional Election & $\begin{array}{c}0.107 \\
(0.072)\end{array}$ & $\begin{array}{l}-0.029 \\
(0.050)\end{array}$ & $\begin{array}{c}-0.036 \\
(0.025)\end{array}$ & $\begin{array}{c}-0.200^{* * *} \\
(0.020)\end{array}$ \\
\hline Ontario & $\begin{array}{c}-0.129 * * \\
(0.056) \\
\end{array}$ & & & \\
\hline $\mathrm{BC}$ & $\begin{array}{l}-0.053 \\
(0.055)\end{array}$ & & & \\
\hline Bavaria & & $\begin{array}{c}-0.539 * * * \\
(0.099)\end{array}$ & & \\
\hline Madrid & & & $\begin{array}{c}0.178 \\
(0.106) \\
\end{array}$ & \\
\hline Zurich & & & & $\begin{array}{c}0.171 * * * \\
(0.026)\end{array}$ \\
\hline Cut1 & $\begin{array}{c}-3.721 \\
(0.144) \\
\end{array}$ & $\begin{array}{c}-4.008 \\
(0.459) \\
\end{array}$ & $\begin{array}{r}-3.800 \\
(0.191) \\
\end{array}$ & $\begin{array}{r}-6.957 \\
(0.878) \\
\end{array}$ \\
\hline Cut2 & $\begin{array}{l}-2.043 \\
(0.205)\end{array}$ & $\begin{array}{l}-2.285 \\
(0.409)\end{array}$ & $\begin{array}{c}-2.338 \\
(0.086)\end{array}$ & $\begin{array}{c}-3.788 \\
(0.317) \\
\end{array}$ \\
\hline Cut3 & $\begin{array}{c}1.054 \\
(0.171) \\
\end{array}$ & $\begin{array}{c}0.871 \\
(0.283) \\
\end{array}$ & $\begin{array}{c}0.938 \\
(0.102) \\
\end{array}$ & $\begin{array}{c}0.384 \\
(0.371) \\
\end{array}$ \\
\hline Clusters & 5 & 3 & 3 & 4 \\
\hline $\mathrm{N}$ & 4,332 & 7,723 & 1,883 & 1,712 \\
\hline Pseudo $\mathrm{R}^{2}$ & 0.054 & 0.060 & 0.042 & 0.052 \\
\hline
\end{tabular}

Standard errors in parentheses.

$* * \mathrm{p}<0.05 ; * * * \mathrm{p}<0.01$.

The effect of being an Early voter on satisfaction with vote choice in Germany, Spain and Switzerland is shown in Table 4. Based on the results of our regressions, we have calculated the probability of thinking that the vote choice was a 'very good decision' for Election Day and early voters in every country. As can be seen, in the three countries, above all in Spain and Switzerland, Election Day voters are happier with their vote choice than early voters. The differences between the two groups of voters are 2 points in Germany and 9 points in Spain and Switzerland. 
Table 4: Predicted probabilities of thinking that the vote choice was a 'very good decision'

\begin{tabular}{l|c|c|c}
\hline & Germany & Spain & Switzerland \\
\hline Election Day Voters & $0.52 * * *$ & $0.51^{* * *}$ & $0.58^{* * *}$ \\
& $(0.09)$ & $(0.02)$ & $(0.07)$ \\
\hline Early voters & $0.50^{* * * *}$ & $0.42^{* * *}$ & $0.49 * * *$ \\
& $(0.09)$ & $(0.02)$ & $(0.07)$ \\
\hline
\end{tabular}

In parentheses, the standard errors.

An obvious concern in our analysis is that the negative relationship between early voting and satisfaction with voce choice does not hold in Canada. The most obvious difference is that early voting in Canada is not by mail, which possibly suggests that early voting at a polling station is 'better' than early postal voting. However, it can be also argued that voters face less uncertainty about candidates' issue positions in Canada than the other three countries due to the lower number of parties. Clearly, this question deserves more research.

\section{Conclusion}

The consequences of early voting for election outcomes is a hot issue in the political debate due to its increasing adoption worldwide. Most of existing research establishes that early voting has a positive effect on turnout. As early voters miss late campaign information, the possible 'dark side' of early voting is that those who voted before Election Day are less satisfied with their vote choice than those who voted on Election Day, once their information is updated after the election.

Using unique data from postelection surveys including a question asking respondents to indicate whether they think that their vote choice was a good or bad decision in elections held in Canada, Germany, Spain and Switzerland, we found that early voters in three of the four countries (Canada is the exception) are slightly less happy with their decision than those voting on the Election Day. Our data confirm that there is a 'cost' in early voting, that is, that there is a higher risk of not being satisfied with one's vote choice, ex post, presumably because of not being able to take into account information that became available late in the campaign. It should be stressed, however, that the cost is small and is not universal. The big question is whether the potential benefit in terms of convenience outweighs this small cost. Further research 
would be needed to address this crucial question. But our study indicates that we should not assume that early voting has no disadvantage.

Our analysis of how early voting affects the quality of vote choice opens up five relevant research questions. First, the fact that Canada is an outlier raises the question whether using advanced voting in polling stations is 'better' than early postal voting or whether the electoral system makes a difference for early voting. Second, apart from knowing whether individuals voted in advance or on the Election Day, it would be very useful to know the exact date when they voted. Third, it is worth exploring whether the relationship between early voting and satisfaction with vote choice depends on the margin of victory in the election. When the election is very close, uncertainty about the identity of the winner increases the importance of late campaign information. Fourth, competition in elections takes place both at the national and district-level. Both levels should be considered in future research. Finally, not all new information available during election campaigns has the same impact on voters. A model about the type of information that voters update during the course of a campaign would be useful to better specify the effect of early voting on satisfaction with vote choice.

\section{Appendix}

Table A1: Election surveys included in the analysis and number of respondents

\begin{tabular}{|c|c|c|c|}
\hline Canada & $\begin{array}{l}\text { Ontario } \\
\text { Quebec } \\
\text { British Columbia }\end{array}$ & $\begin{array}{l}2011 \text { provincial election } \\
2015 \text { federal election } \\
2012 \text { provincial election } \\
2015 \text { federal election } \\
2015 \text { federal election }\end{array}$ & $\begin{array}{c}571 \\
1,097 \\
674 \\
989 \\
1,001\end{array}$ \\
\hline Germany & $\begin{array}{l}\text { Bavaria } \\
\text { Lower Saxony }\end{array}$ & $\begin{array}{l}2013 \text { state election } \\
2013 \text { federal election } \\
2013 \text { state election } \\
2013 \text { federal election }\end{array}$ & $\begin{array}{c}2,874 \\
3,242 \\
564 \\
581\end{array}$ \\
\hline Spain & $\begin{array}{l}\text { Catalonia } \\
\text { Madrid }\end{array}$ & $\begin{array}{l}2011 \text { national election } \\
2012 \text { regional election } \\
2011 \text { national election }\end{array}$ & $\begin{array}{l}603 \\
632 \\
650 \\
\end{array}$ \\
\hline Switzerland & $\begin{array}{l}\text { Lucerne } \\
\text { Zurich }\end{array}$ & $\begin{array}{l}2011 \text { cantonal election } \\
2011 \text { federal election } \\
2011 \text { cantonal election } \\
2011 \text { federal election }\end{array}$ & $\begin{array}{l}623 \\
245 \\
645 \\
199\end{array}$ \\
\hline
\end{tabular}




\section{References}

Blais, André. 2004. "How Many Voters Change their Mind in the Month Preceding and Election?" PS: Political Science \& Politics 37: 801-803.

Blais, André. 2010. “Making Electoral Democracy Work”. Electoral Studies 29: 169-70.

Blais, André, Fernando Feitosa and Semra Sevi. 2017. "Was my decision to vote (or abstain) the right one?" Party Politics https://doiorg.sare.upf.edu/10.1177/1354068817722058

Brady, Henry E. and Richard Johnston (eds.). 2006. Capturing Campaign Effects. Ann Arbor: University of Michigan Press.

Burden Barry C., David T. Canon, Keneth R. Mayer and Donald P. Moynihan. 2013. "Election Laws, Mobilization, and Turnout: The Unanticipated Consequences of Election Reform”. American Journal of Political Science 58: 95-109.

Fullner, Elliot B. 2015. "Early Voting: Do More Sites Lead to Higher Turnout?" Election Law Journal: Rules, Politics, and Policy. 14: 81-96.

Granda, Peter, Christof Wolf and Reto Hadordn. 2010. "Harmonizing Survey Data". In Survey Methods in Multinational, Multiregional, and Multicultural Contexts, eds. Janet A. Harkness, Michael Braun, Brad Edwards, Timothy P. Johnson, Lars Lyberg, Peter Ph. Mohler, Beth-Ellen Pennell and Tom W. Smith. New Jersey: Wiley.

Gronke, Paul, Eva Galanes-Rosenbaum and Peter A. Miller. 2007. "Early Voting and Turnout". PS: Political Science and Politics 40: 639-645.

Gronke, Paul, Eva Galanes-Rosenbaum, Peter A. Miller and Daniel Toffey. 2008. “Convenience Voting”. Annual Review of Political Science 11: 437-455.

Heck, Ronald H. and Scott L. Thomas. 2000. An Introduction to Multilevel Modelling Techniques. Mahwah, NJ: Laurence Erlbaum Associates.

Hox, Joop J. 2002. Multilevel Analysis: Techniques and Applications. Mahwah, NJ: Lawrence Erlbaum Associates.

Holly, Ann Garnett. 2016. "Early Voting: Comparing Canada, Finland, Germany and Switzerland". Canadian Political Science Association Meeting, Calgary, AB.

Jennings, Will and Christopher Wlezien. 2016. The Timeline of Elections: A Comparative Perspective. American Journal of Political Science 60: 219-233.

Mass, Cora J.M. and Joop J. Hox. 2004. "Robustness Issues in Multilevel regression Analysis.” Statistica Neerlandica 58:127-37. 
Meredith, Marc and Neil Malhotra. 2011. "Convenience Voting Can Affect Election Outcomes". Election Law Journal: Rules, Politics, and Policy 10: 227-250.

Stein, Robert M. 1998. “Introduction: Early Voting.” Public Opinion Quarterly 62: $57-69$.

Stein, Robert M. and PA Garcia-Monet. 1997. "Voting Early but not Often." Social Science Quarterly 78: 657-671.

Stein, Robert M. and Greg Vonnahme. 2010. "Early, Absentee, and Mail-In Voting”. In Jan E. Leighley (ed.). Oxford Handbook of American Elections and Political Behavior. Oxford: Oxford University Press.

Vivekinan, Ashok, Feder Daniel, McGrath Mary and Hersh Eitan. 2016. "The Dynamic Election: Patterns of Early Voting Across Time, State, Party, and Age". Election Law Journal: Rules, Politics, and Policy. 15: 115-128. 